\title{
Free to think? \\ Epistemic authority and thinking for oneself
}

\author{
Philosophical Lecture \\ read 26 June 2018 \\ URSULA COOPE
}

Abstract: People generally agree that there is something valuable about thinking for oneself rather than simply accepting beliefs on authority, but it is not at all obvious why this is valuable. This paper discusses two ancient responses, both inspired by the example of Socrates. Cicero claims that thinking for yourself gives you freedom. Olympiodorus argues that thinking for yourself makes it possible to achieve understanding, and that understanding is valuable because it gives you a certain kind of independence. The paper asks how insights from these thinkers might bear on a question about the role of experts in a democracy. As citizens, we make judgements about many matters that fall within the domain of some expertise. Should thinking for oneself play an important role in such cases, or must the responsible citizen simply defer to expert authority?

Keywords: Cicero, Olympiodorus, Socrates, freedom, understanding, authority, expertise.

In an interview during the Brexit campaign, Michael Gove claimed that the public had 'had enough of experts'. When Gove was asked why the public should trust him, rather than the experts, he explained: 'I'm not asking the public to trust me. I'm asking the public to trust themselves. ${ }^{1}$ In making these comments, Gove had in mind experts on a certain particular topic - economic experts. ${ }^{2}$ His claim was that on this topic, it is important to think for oneself rather than simply to accept the beliefs of authority figures. In a later discussion, he went on to connect this with being citizens

\footnotetext{
${ }^{1}$ Interview by Faisal Islam, Sky News, 3 June 2016.

${ }^{2}$ Chatham House Interview, 3 March 2017. As Gove says, his point was that 'people have had enough of experts from organisations with acronyms that have got things so wrong in the past'. He was not arguing, for instance, that one should never seek medical advice from a doctor.
} 
of a democracy. He said, 'If you are going to leave it to the experts, why have a democracy?'3

The slogan 'think for yourself; don't just accept views on authority' works because we can all agree that there is something right about the advice it gives. But this slogan is also potentially dangerous because there are multiple ways in which it could be understood, and on some readings, it provides advice that is harmful. If we are to work out what is right about this slogan, then we need to be able to explain why thinking for oneself is valuable. But this is not an easy task. How, for instance, should independent-mindedness be distinguished from mere pig-headedness? The question becomes particularly pressing when we are thinking about fields in which there are acknowledged experts. In the modern context, large fields of knowledge have become rather specialised. It is just not plausible that any one ordinary member of the public will be able to acquire a good understanding of economics, climate change, food safety, fracking, and so on. ${ }^{4}$ But these are all matters on which we need to make up our minds in our role as citizens. Of course, having expert knowledge about such matters does not by itself tell you what to do. Even if we have reliable information about climate change or economics, there is a further question about how we should act in the light of this information. Nevertheless, being well informed about the likely effects of different policies is surely necessary for coming to the right decisions. And often, consulting an expert maximises one's chances of being well informed. Is there nevertheless something important about thinking for oneself, even about questions that fall within the domain of some expertise?

The claim that there is something especially valuable about thinking for oneself is often associated with the Enlightenment. ${ }^{5}$ But it is a claim that has roots in ancient philosophy. Ancient discussions of this claim are often framed as attempts to make sense of Socrates's practice of asking questions rather than simply telling his interlocutors the answer.

Socrates defends this method of questioning in a striking remark in Plato's Alcibiades. The context is a discussion of whether justice is beneficial. Alcibiades wants Socrates to tell him what to think. Socrates responds with a striking piece of advice - advice that is weirdly similar to Gove's. He says: 'if you don't hear yourself saying that just things are beneficial, then don't believe anyone else saying [this]' (Alcibiades 114e). ${ }^{6}$ Michael Gove said that the public should 'trust themselves' rather

\footnotetext{
${ }^{3}$ Quoted in Ince (2017).

${ }^{4}$ This point is made vividly by Millgram (2015: Chapter 2).

${ }^{5}$ Kant (1784: 58) claimed that 'Enlightenment is mankind's exit from its self-incurred immaturity. Immaturity is the inability to make use of one's own understanding without the guidance of another.'

${ }^{6}$ In taking the sentence thus, I follow Denyer (2001: 142, 'you shouldn't take it on trust from anyone else'), Döring (2016: 'wenn du nicht aus deinem eigenen Mund hörst, dass die gerechten Handlungsweisen
} 
than believing what either he or the economic experts said; similarly, Socrates advises Alcibiades to think for himself, instead of simply taking on the beliefs of another. Presumably, Socrates's advice (like Gove's) is not intended to be completely general. There is nothing to suggest that Socrates would advise Alcibiades never to trust anyone giving him directions to the marketplace. The context is a discussion of justice and its relation to advantage. Socrates is claiming that, at least in relation to such matters, it is better to think for oneself rather than simply accepting beliefs on authority.

Of course, the fact that the topic under discussion is justice makes Socrates's advice importantly different from Gove's. Arguably, questions about justice differ from questions about economics, in that they do not fall within the domain of any specialised area of expertise. Nevertheless, I want to argue that Socrates's advice raises some of the same questions as Gove's. In particular, it should prompt us to ask what exactly is valuable about thinking for oneself when one lacks understanding. In the context of the Alcibiades, Socrates's advice raises this question in a specially pointed way. Socrates has just argued that Alcibiades does not understand justice and injustice (112e). Why, then, does Socrates advise Alcibiades to think for himself, rather than to seek out someone who does have understanding of the matter? Given that Alcibiades lacks understanding, wouldn't he be more likely to arrive at true beliefs by consulting someone who has such understanding, rather than by attempting to think things out for himself? But if the reason for thinking for oneself is not that this makes one more likely to acquire true beliefs, is there some other important benefit that might be gained by following Socrates's advice?

In this essay, I look at two very different ancient attempts to answer these questions, both from philosophers who take their inspiration from Socrates. The first is by Cicero, an orator and philosopher of the 1st century BC, the second by Olympiodorus, a philosopher of the 6th century $\mathrm{AD}$. These ancient discussions are particularly interesting because both Cicero and Olympiodorus take for granted the value of being influenced in certain ways by one's illustrious predecessors, so there is a sense in which

\footnotetext{
auch nützlich sind, dann glaub es keinem anderen, wenn er es behauptet'), and Marboeuf \& Pradeau (1999: 'Et si tu n'entends pas de toi-même que le juste est l'avantageux, ne le crois pas d'un autre qui te le dirait'). This is also how the ancient commentators understood the remark (Olympiodorus, In Gorg. 41.9, 19.1, Prolegomena 10, 8-9, Philoponus, De Aeternitate Mundi 445). By contrast, Hutchinson (1997: 571) translates 'If you don't hear yourself say ..., then don't believe anything else I say', and Jowett (1892): 'and if you do not hear the words that the just is the expedient coming from your own lips, never believe another man again'. Neither of these gets the point right. Socrates is saying that Alcibiades should not be persuaded of this claim about justice unless he hears himself saying it. That is what justifies using the question and answer method. It would not be relevant, in attempting to justify this method, to say that Alcibiades should not believe anything else Socrates says or anything anyone else says, unless he first hears himself saying that just things are beneficial. If Socrates were making either of these points, he would simply be making a confident prediction that Alcibiades would in fact end up being persuaded. But that would not explain the importance of the question and answer method.
} 
they both recognise the value of a kind of deference to authority. Both claim to be following the example of Plato's Socrates, and each of them identifies with a different long-standing philosophical tradition. Cicero is an Academic sceptic, Olympiodorus a Platonist. Olympiodorus rather charmingly appeals to no less than two authorities in support of his view that we should not form our beliefs on the basis of authority. He says, referring to the passage we have just been discussing from the Alcibiades: 'Plato himself urges us not to believe him unreservedly and indiscriminately ( $\dot{\alpha} \pi \lambda \tilde{\omega} \varsigma$

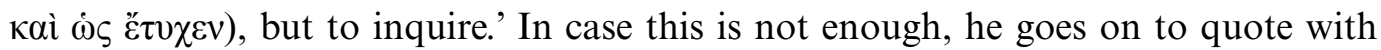
approval his teacher, Ammonius. Ammonius had obviously been irritated by other Platonists who went around saying 'Plato said so', when asked to justify their beliefs. Ammonius advises that when you encounter such people you should reply, 'I am not persuaded unless he [Plato] added a demonstrative argument' (In Gorg. 41.9). Thus, Olympiodorus claims that both Plato himself and Ammonius urge us to think for ourselves instead of simply forming beliefs on the basis of authority. Given the ways in which both Cicero and Olympiodorus take their inspiration from earlier philosophers, they are both faced with the question of why it would be a mistake to adopt the practice of forming beliefs on the authority of those earlier philosophers. As we shall see, their answers to this question are very different. Both suggest that thinking for ourselves is a way of preserving a kind of freedom or independence, but they differ in what they take this freedom or independence to consist in.

My paper has three parts. In the first part, I focus on Cicero. Cicero claims that we can preserve our freedom by adopting a kind of scepticism. I argue that this fails to explain either the value of thinking for oneself or the value of the Socratic practices Cicero claims to be following. In the second part, I turn to Olympiodorus, who provides an interesting contrast to Cicero. Olympiodorus claims that thinking for oneself is a necessary condition for having understanding, so thinking for oneself is valuable because having understanding is valuable. I argue that there is something right about this account, but that it fails to explain a crucial feature of Socratic practice. Olympiodorus cannot explain the value Socrates places on thinking for oneself even when such thinking does not result in understanding. In the third and final section of my paper, I ask about the value of thinking for yourself when you do not have any expectation of achieving full understanding. I end by suggesting a way we might use what we have learned from Cicero and Olympiodorus in order provide a tentative answer to this question. 


\section{CICERO: FREEDOM AND THE SCEPTIC}

Cicero argues that the members of his philosophical school, the Academic sceptics, enjoy a certain kind of freedom. Their teachers follow the example of Socrates and leave their followers to make up their minds for themselves. By doing so, they leave the judgement of their followers 'wholly free' (integrum ac liberum, De Div. 2.150). Moreover, he claims that the Academic sceptics are unique in enjoying this kind of freedom. The Academic sceptics are 'freer and less constrained' than other philosophers because they are not compelled by any necessity to adopt everything that has been laid down and practically imposed on them by their teachers (Acad. 2.8-9). ${ }^{7}$ Elsewhere, Cicero writes of the 'freedom' which, he says, 'is allowed to our school of philosophy alone' (libertate, qua nobis solis in philosophia licet uti, Tusc. Disp. 5.83). As far as we know, Cicero was the first philosopher to connect scepticism with freedom in this way, so these remarks about freedom are particularly interesting. In this section of my paper, I ask what exactly he means by 'freedom' here, and why he thinks that the sceptics are unique in enjoying such freedom.

According to Cicero, the Academic sceptic is characterised as someone who engages in certain kinds of intellectual practices, rather than as someone who accepts any particular positive claims about how things are. The Academic sceptic does not take herself to have any knowledge, so being a sceptic cannot be a matter of signing up to any particular doctrine (not even to the doctrine that knowledge is impossible). ${ }^{8}$ The intellectual practices that characterise the sceptic are grounded in the ability to come up with arguments on both sides of any question. For any question, the sceptic is able to compare these arguments and 'to bring out whatever can be said for each view' (De Div. 2.150). When you present her with an argument for a certain conclusion, she will call to mind an argument on the other side. Because she follows this practice, the sceptic has never been fully convinced by any argument that has been presented to her.

Given this rough characterisation of scepticism, we can begin to see why Cicero claimed that the sceptic is uniquely free. In the Academica, he points out that philosophers often sign up to a particular school when they are too young to make an informed judgement. For instance, they might do so under the influence of some charismatic friend (see Acad. 2.8). Those young people who join the Academics are left freer than others because they are not taught particular doctrines while they are

\footnotetext{
${ }^{7}$ The 'everything' (omnia) here must, I think, be rhetorical exaggeration. Surely Cicero does not think that other philosophers are compelled to believe everything that their teachers say.

${ }^{8}$ Cicero is aware of the potential contradiction that would be involved if the sceptic were to claim to know that knowledge is impossible. The point is made at Academica 2.109-10: just as the sage 'holds his other doctrines as persuasive, not as perceived, so he does this itself, that nothing can be perceived'.
} 
immature and easily influenced. As Cicero says, the procedure of the Academy is to 'introduce no judgement of its own', but instead to inculcate a particular method of arguing (De Div. 2.150).

However, Cicero's claim cannot simply be that young Academics are free because they take on their teachers' intellectual practices instead of taking on their teachers' beliefs. That claim would be open to an obvious objection. If we are worried about the way in which the teacher's influence threatens to undermine the student's freedom, then we should be at least as worried about the teacher's influence on the student's intellectual practices as we are about the teacher's influence on the student's beliefs. Arguably, ingrained intellectual practices are at least as difficult to change as beliefs. And it is easy to imagine intellectual practices that would undermine a student's freedom. For instance, you could bring a student up to believe whoever speaks the loudest. This kind of upbringing would undermine her ability to develop intellectual independence, and would do so without getting her to accept any particular positive doctrine.

Cicero's point must be that Academic intellectual practices are such as positively to promote freedom. ${ }^{9}$ It is the Academic practice of arguing on both sides that is important here. The Academic sceptic, as Cicero describes her, has a certain kind of intellectual armoury. If you attempt to convince her of something by argument, she will always be able to come up with an argument on the other side. So what we need to ask is how this practice promotes the sceptic's freedom. Cicero cannot be saying that the sceptic is immune from ever being convinced by argument, and in that sense free from all argumentative influence. He makes it quite clear that the Academic sceptic is searching for the truth. Such a sceptic remains open to the possibility of being convinced by argument, should she ever encounter a conclusive proof. ${ }^{10}$ For Cicero, the sense in which the sceptic is free is that she has an ability to resist being convinced by arguments that fall short of being conclusive proofs. Her training thus guarantees that she will never be tricked by argument into believing something false, or into believing something on inadequate grounds.

\footnotetext{
${ }^{9}$ Thorsrud (2012: 141) takes Cicero's freedom to consist in his willingness to allow himself free reign to have opinions. Cicero says he himself has opinions in this way, but the sage would not (Acad. 2.66). Thorsrud comments: 'Cicero's intellectual roaming refers to his cherished Academic freedom. So it is not simply a synonym for error and he is not simply critical of his fallibility.' But I see no reason for taking this to be what Cicero has in mind by the freedom of the Academic, and hence attributing to Cicero the claim that he is free in a way a true sage would not be. If freedom is a benefit that comes from being a sceptic, it is presumably not a benefit one only gets insofar as one fails to be a sage and hence fails to be a perfect sceptic.

${ }^{10}$ For the claim that the Academic sceptic is searching for the truth, see Acad. 2.7. This distinguishes her both from the negative dogmatist (who thinks knowledge is impossible) and from the Pyrrhonian sceptic who aims at suspension of belief.
} 
This shows that the sceptic is free from a certain particular kind of external influence. However, there is also another strand to Cicero's remarks about freedom. In his Tusculan Disputations, he suggests a further way in which the sceptic is uniquely free. The sceptic, he says, is free to say different things at different times. Cicero makes this point in response to an objection. His interlocutor has just accused him of relying on a certain claim that is inconsistent with a claim he defended in another work (the De Finibus) ${ }^{11}$ Cicero's response to this objection is revealing. He says that because he is an Academic sceptic, this kind of objection cannot touch him. He is not bound, as other philosophers are, to be consistent with what he said on some earlier occasion. For this reason, he and his fellow sceptics are free in a way that no other philosophers are:

Use that method with others, who argue according to set rules: we live in the moment; we say whatever strikes our minds as persuasive, so we alone are free. (Tusc. Disp. 5.33)

Cum aliis isto modo, qui legibus impositis disputant: nos in diem vivimus; quodcumque nostros animos probabilitate percussit, id dicimus, itaque soli sumus liberi.

What does Cicero mean by this claim that the sceptic is uniquely free to say different things at different times? ${ }^{12}$ The context makes it clear that his point is that a certain kind of objection has no force against the sceptic. When the sceptic appears to be saying something that is inconsistent with what she said on an earlier occasion, it isn't relevant to bring up this apparent inconsistency as an objection. ${ }^{13}$

Thus, to understand Cicero's claim, we need to understand why bringing up such inconsistency is usually regarded as an objection, and why Cicero thinks that the sceptic is unique in not being vulnerable to this objection. Why should it matter to me if someone points out that what I am saying now is incompatible with something I said

\footnotetext{
${ }^{11}$ It is a claim about whether the view that virtue is sufficient for happiness is compatible with the view that things other than virtue can be genuine goods.

${ }^{12}$ For the claim that the sceptic says different things at different times, see also Acad. 2.121 'now this, now that seems more persuasive' (modo hoc, modo illud probabilius videtur). See also Acad. 2.134.

${ }^{13}$ If this is his point here, then these remarks are not merely an expression of scepticism about general rules of conduct. Elsewhere, he suggests that the right thing to do depends upon the particular circumstances, and hence that an allegedly general rule might be applicable in some circumstances but not others. Woolf (2015: 200) points out that Cicero defends this view about rules in De Officiis: 'the notion that there are, or ever were, a fixed set of rules or positions that could save us from disaster, if only we applied them consistently, is the great myth that On Duties attempts to debunk.' But the alleged inconsistency between Tusc. Disp. 5.33 and De Finibus is not over the appropriateness of applying some general rule of conduct, but rather over a general theoretical claim about the relation between virtue and happiness.
} 
in the past? After all, whether or not I am a sceptic, I can surely change my mind. ${ }^{14}$ The answer is that we ordinarily take ourselves to be accountable in a certain way for our past statements. When you object that what I am claiming now is inconsistent with what I said earlier, you need not be ignoring the possibility of my changing my mind. Your point is that I owe you an explanation of a certain type. If I have changed my mind, I can be called on to give an account of the grounds on which I now reject the claim that I accepted earlier.

Thus, if Cicero's remarks here are meant to explain why he is absolved from any need to respond to the charge of inconsistency, he must be claiming that the sceptic is not accountable in this way. ${ }^{15}$ She is not accountable because she never commits herself to any claims about how things are, as other philosophers do. Even when she utters declarative sentences, she is merely expressing how things seem to her at that time, not making a claim about how things really are. She does not owe us an account of why she changed her mind, because she never really made up her mind in the first place. Her earlier statement expressed how things struck her then, on the basis of evidence that was salient to her then; her later statement expresses how things strike her

\footnotetext{
${ }^{14}$ I take it that Cicero cannot be claiming that the sceptic is unique in being able to change her mind. Other philosophers can do that too. Admittedly, dogmatists may find it more difficult to change their minds. There are two reasons for this. (i) As Katharine O'Reilly has pointed out to me, it may be more difficult for a certain systematic type of philosopher to change her mind. If her views are organised in a philosophical system, then she might not be able to change her mind about one thing without changing her mind about everything else. In De Finibus 5.83-4, Cicero describes the doctrines of the Stoics as forming this kind of system: each part agrees with every other, and 'as in geometry, if you grant the first, you must grant everything'. However, his point in Tusc. Disp. 5.33 cannot simply be that the sceptics are free insofar as they do not have views that are systematic in this way. For he does not think that all dogmatic philosophies are systematic, as Stoicism is. The point about systematicity might show how the sceptic can change her mind more easily than the Stoic, but it would not show how the sceptic can change her mind more easily than the Epicurean. (ii) There is, nevertheless, one relevant way in which the sceptics differ from all dogmatic philosophers. There are certain first-order beliefs that a dogmatic philosopher must accept if she is to remain a member of her school. (I am grateful to Raphael Woolf and Tobias Reinhardt for pressing me on this.) For instance, an Epicurean cannot reject hedonism without ceasing to be an Epicurean. Sceptics do not face this kind of constraint. However, if Cicero's claim to freedom simply amounted to this point, he could not appeal to such freedom in dismissing as irrelevant the charge of inconsistency. The fact that you have no allegiance to any particular dogmatic school does not absolve you from the obligation to explain why you are now committed to some claim you earlier rejected.

${ }^{15}$ In fact, to defend himself against the opponent's objection here, all Cicero really needs to show is that he cannot be called upon to account for a rather remote kind of inconsistency: between his remarks in this conversation and his remarks in another philosophical work. However, his explanation of why he is under no obligation to account for this inconsistency seems also to apply more generally. If the reason why he is free to say inconsistent things at different times is just that all his remarks are mere expressions of how things then seem to him, this will also allow him to dismiss, in just the same way, any attempt to object that what he is saying now is inconsistent with what he said a little earlier in the same conversation.
} 
now, on the basis of evidence that is salient to her now. As she never made any commitment to things being thus and so, she cannot be called on to explain the grounds on which she no longer holds herself to that commitment. ${ }^{16}$

Cicero's claim, then, is that the sceptic is free in two related ways. As we have seen, the sceptic is free from a certain kind of argumentative influence: she will never be fully convinced by inconclusive arguments. But she is also free from a certain kind of responsibility for what she says. She never commits to things being a certain way, so she can say different things at different times without being called to account.

If that is Cicero's view, how should we assess it? I want to argue that freedom, so understood, is only valuable in a very qualified way. Of course, no one could dispute the value of being able to identify bad arguments and hence avoid being deceived by them. However, the sceptic's method of avoiding being deceived has significant costs. The first reason for this is obvious. The sceptic gives absolute priority to avoiding false belief. She resists being fully convinced by any argument that falls short of a conclusive proof, and she understands the notion of 'conclusive proof' in such a way that no argument she has ever encountered qualifies as one. But it is not obviously right to prioritise avoiding false belief over all other epistemic aims. It is true that the sceptic will avoid believing falsehoods; but in following her preferred method, she will also miss out on a lot of truths.

That is the obvious way in which the sceptical method seems to fall short. However, I want to claim that there is also a second, more subtle, cost of following the sceptic's method. This method, I suggest, distorts the way in which the Academic sceptic engages in argument with others. As we have seen, Cicero boasts that he cannot be held accountable for any of the things he has said, because in making declarative utterances he was not really expressing a view about how things are. He claims that this lack of accountability amounts to a kind of freedom. But I want to suggest that in fact, this refusal to take responsibility for what one says undermines the possibility

${ }^{16}$ Cicero (or the character who represents him) provides various descriptions of what the sceptic is doing in uttering declarative sentences. In the passage above, he says that 'we say whatever strikes our minds as persuasive' (quodcumque nostros animos probabilitate percussit, id dicimus). Elsewhere, he says that the practice of the Academics is to 'approve what seems similar to the truth' (ea probare quae simillima veri videantur, De Div. 2.150). The interpretation of these remarks is contested. What does Cicero mean by 'persuasiveness' (probabilitas)? What is involved in 'approving' something as similar to the truth? According to one interpretation, when the sceptic says what strikes her mind as persuasive (or similar to the truth), she is saying what she thinks is likely to be true. (For this view, see Thorsrud $(2010,2012)$.) According to another interpretation, Cicero holds that the sceptic should make no claim about what is objectively true. Instead, she merely tells us how things strike her. (For this view, see Wynne (2018) and Brittain $(2006,2015)$.) Cicero's remarks about the sceptic's freedom to say different things at different times make much better sense on the latter interpretation. If the sceptic were to make incompatible claims at different times about what was likely to be the case, then she (like anyone else) would owe us an account of the grounds on which she has changed her mind. 
of genuine argumentative engagement with others. There is a certain type of argumentative progress that is only possible when the parties to the discussion are genuinely committed to the claims they make.

This suggestion is speculative. For a full defence, one would need to examine particular examples of ways in which arguments go well or badly. If we look at the examples given in Platonic dialogues, they suggest, I think, that Plato himself appreciated this point about the nature of argumentative engagement. Although Cicero often claims to be following the example of Socrates, ${ }^{17}$ in fact, someone who followed Cicero's recommendations would have much more in common with the sophists (as depicted by Plato) than with Socrates. In the Euthydemus, it is the sophists who boast of their ability to refute whatever position their opponent might try to defend. ${ }^{18}$ In the same dialogue, it is the sophist Dionysodorus who objects that it is irrelevant to 'bring up now what we said in the beginning' $(287 \mathrm{~b})^{19}$ (a remark echoed by David Davis, when challenged about predictions he made before the Brexit vote: 'That was then, this is now. ${ }^{20}$ ) Socrates does not boast about a freedom to say different things at different times. On the contrary, in the Gorgias, he emphasises that he continually says the same things, and accuses Callicles of never sticking to the same things: 'You claim that I'm always saying the same things, and you criticize me for it, whereas I, just the opposite of you, claim that you never say the same things about the same subjects' (491c). In both cases, it is not Socrates but his interlocutor who refuses to commit to any view. These passages almost read as a warning to those, like Cicero, who are tempted to suppose that they could follow in Socrates's footsteps by being sceptics.

I started this paper with the question why it is valuable to think for yourself rather than simply believing on the authority of others. Cicero's answer is that a certain kind of sceptical thinking can enable you to avoid being deceived by others. If Cicero is right, then this method can enable you to avoid being deceived about a topic even when you do not yourself have understanding about that topic. So Cicero gives us an

\footnotetext{
${ }^{17}$ For instance, he claims to be following Socrates's example in refusing to reveal his own views. See, for example, Tusc. Disp. 5.11, De Natura Deorum 1.11, De Div. 2.150. At Acad. 1.46, Cicero suggests that Plato, by writing dialogues, also avoided putting forward any view of his own: Plato in whose books nothing is affirmed and there is much arguing pro and contra, all things are inquired into and nothing is said to be certain' (cuius in libris nihil adfirmatur et in utramque partem multa disseruntur, de omnibus quaeritur, nihil certi dicitur, Acad. 1.46). For a helpful discussion of Cicero's references to Socrates, see Gorman (2005).

${ }^{18}$ At 275e Dionysodorus says, 'I may tell you beforehand, Socrates, that whichever way the boy answers, he will be refuted.'

${ }^{19}$ Thanks to M. M. McCabe, for pointing this out to me.

${ }^{20}$ Response to a question from Hilary Benn at the Brexit Select Committee, about his earlier claim that within two years of the Brexit vote the UK would have negotiated a 'free trade area massively larger than the EU'. Quoted in Belam (2018).
} 
answer to our question about the value of thinking for yourself even when you do not have understanding. However, I have argued that this provides, at best, only a very limited answer. Avoiding being deceived is all very well, but surely there are also more positive benefits to be gained from thinking for ourselves. In the second part of the paper, I turn, for contrast, to an account that attempts to explain these positive benefits. This account is found in the work of the 6th-century Neoplatonist, Olympiodorus. As we shall see, Olympiodorus holds that thinking for oneself is valuable because such thinking is necessary for achieving understanding.

\section{OLYMPIODORUS: SELF-MOVEMENT AND PERSUASION}

Olympiodorus was a commentator on the works of Plato and Aristotle, and a follower of Plato. In several places, he explains that Plato himself advises us to think for ourselves rather than believing on the basis of authority. To show this, he invokes Socrates's advice to Alcibiades, which he paraphrases: 'unless you hear yourself speaking, don't put your trust in the words of another'. ${ }^{21}$

How, then, does Oympiodorus explain the value of thinking for yourself? As it happens, Olympiodorus wrote a commentary on Plato's Alcibiades that has survived, so we can look at what he says about these lines. Olympiodorus comments that the reason why it is important for Alcibiades to answer for himself is 'so that his arguments would not be formed from without, like a lifeless vessel that holds its water

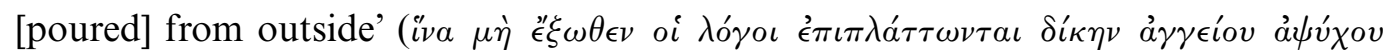

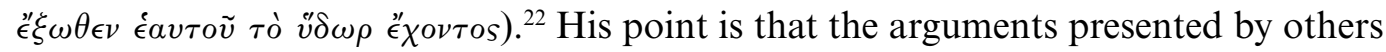
will only benefit us if we can in some sense make them our own. Unless we do this, we will merely be like containers into which arguments have been poured. ${ }^{23}$ Of course, so

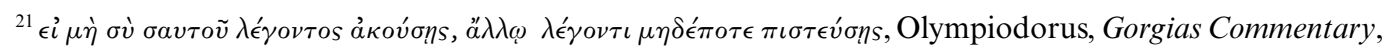

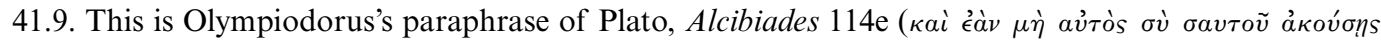

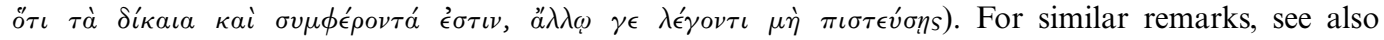
Olympidorus's Gorgias Commentary 19.1, and Prolegomena 10. Philoponus also invokes this advice from the Alcibiades to justify not simply following authorities: 'Indeed we shall refuse to believe anything that lacks rational demonstration: if you don't hear yourself saying [something], says Plato, you should never believe someone else when they say [it]' (Philoponus, De Aeternitate Mundi 445).

${ }^{22}$ Griffin translation. In Alc. 114, 9-10. He goes on to say that refutations ought instead to be presented from one's own self, so that learning is recollecting; 'rather, the refutations ought to be presented from

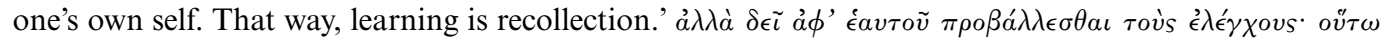

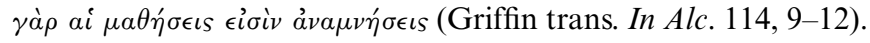

${ }^{23}$ For the comparison between a vessel being filled up and one person's learning from another, see Plato, Symposium 175c7-e2 (where Socrates says it would be wonderful if we could acquire wisdom so easily), and Phaedrus 235cd, where Socrates suggests that his speeches arise from his being filled up with other people's words, like a jar, while remaining ignorant himself. 
far this is just a metaphor. We need to know what exactly it is to make an argument our own, and how we benefit from doing so. ${ }^{24}$

For a clue to this, I turn to an interesting passage in which Olympiodorus connects having understanding with being self-moved. This is in his commentary on another Platonic dialogue, Plato's Gorgias. Olympiodorus is discussing a distinction Socrates draws between two kinds of persuasion. ${ }^{25}$ One way to be persuaded is to learn; and those who have learned have understanding $(\dot{\epsilon} \pi \iota \sigma \tau \eta \dot{\eta} \mu \eta)$. The other way to be persuaded is to become convinced without having learnt. Those who have been persuaded in this way have mere belief ( $\left.\pi i^{\prime} \sigma \tau \iota s\right)$. In Plato's Gorgias, Socrates and Gorgias agree that teaching produces persuasion of the first kind and hence produces understanding, whereas rhetoric produces persuasion of the second kind, and hence produces mere belief (Gorgias 454e). What Olympiodorus adds to this is the claim that those who

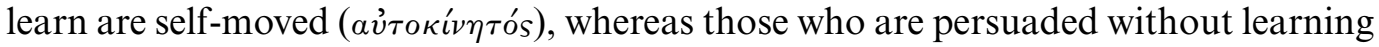

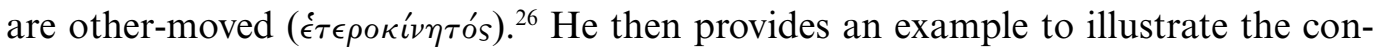
trast between these two ways of being persuaded. When you approach someone who has been persuaded in the first way (having learned), and ask him whether the soul is immortal, he

is not other-movedly carried along so as to say 'Yes, immortal, that's what Plato and Aristotle think'. Instead, he tries self-movedly to bring forth demonstrations from within.

\footnotetext{
${ }^{24}$ In this passage, Olympiodorus has in mind the kind of arguments by which we recognise that we are mistaken ('refutations' as he calls them). There might, of course, be special reasons why it is better to be refuted by an argument you produce for yourself. For instance, if you produce the argument for yourself, you are less likely to resist its conclusion on account of hurt pride. (At 113, 20 in the Alcibiades Commentary, Olympiodorus says that refutation is most efficacious when we refute ourselves because then we are more fully persuaded. Proclus, in his own commentary on the Alcibiades, makes the point that we are more likely to be persuaded when we refute ourselves, since 'we are less annoyed when we are refuted by ourselves than when we are refuted by others', 279, 9-10). However, there is reason to think that Olympiodorus is also making the more general point that we need to produce arguments from ourselves if we are to learn from them. This, at least, is suggested by the fact that he goes on to refer to the Platonic view that we learn by recollection, which involves recovering knowledge from within (In Alc. $114,12)$.

${ }^{25}$ Note that 'persuasion' here is to be understood not as the process of persuading but as the persuasion that is produced by it. Olympiodorus makes this clear in his commentary $(6,1,3-5)$, when he distinguishes between 'persuading' (for which he uses the infinitive verb, $\tau \grave{o} \pi \epsilon i \theta \epsilon v$ ), and 'persuasion' (for which

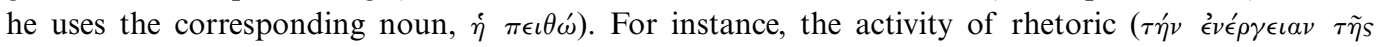

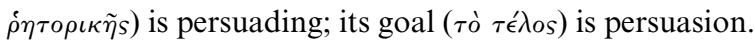

${ }^{26}{ }^{6}$ For as Socrates himself will say, one kind of persuasion is produced by teaching, the other is produced by trust. And the kind that is produced by teaching is self-moved and of those who see, while the kind

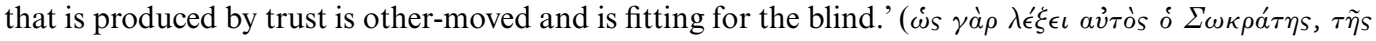

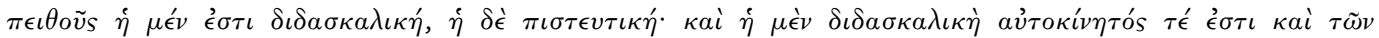

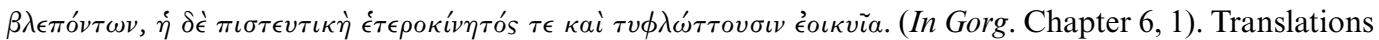
from the Gorgias Commentary are my own, but I have benefited from consulting Jackson et al. (1998).
} 


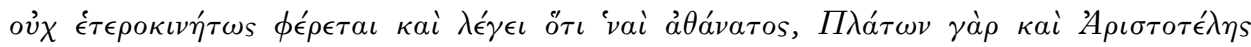

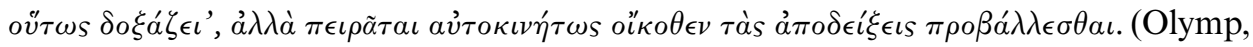
In Gorg. 6, 1)

In other words, believing on authority is an example of the other-moved kind of persuasion, whereas 'bringing forth demonstrations' is an example of the self-moved kind of persuasion. ${ }^{27}$

Olympiodorus's comments suggest that achieving understanding is always a matter of being self-moved. Even when you are being taught by someone else, if you are to achieve understanding you must in some sense bring forth the demonstrations from within you. Thus, thinking for yourself is valuable because it is necessary for achieving understanding. In what follows, I shall first ask why Olympiodorus holds that understanding must come from within oneself, and then go on to discuss why he thinks that understanding is especially valuable.

To answer these questions, it will be helpful to know a little more about Olympiodorus's view of understanding. For Olympiodorus, having understanding involves not only knowing that something is true but also understanding why it is true. Much of our ordinary knowledge does not count as understanding in this demanding sense. Olympiodorus's account of what it is to have understanding is derived from Aristotle. On this account, understanding why something is true requires having the ability to infer its truth on the basis of a demonstration. A demonstration is a valid deductive argument (a syllogism) from true premises that are explanatory of the conclusion. ${ }^{28}$ To understand the conclusion is to believe it because one grasps the way in which it is explained by the premises.

Olympiodorus thinks that such demonstration-based understanding must come from within oneself. We need to ask why. If a reliable authority figure provides you with the right kind of demonstrations, why can't you acquire understanding by simply

\footnotetext{
${ }^{27}$ In Plato's Alcibiades, Socrates implies that Alcibiades needs to answer for himself if he is to be 'truly

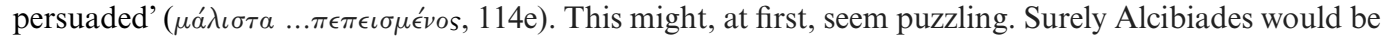
just as thoroughly persuaded if he credulously accepted the views of another? Olympiodorus's distinction between two different kinds of being persuaded perhaps suggests an answer. To be persuaded in the self-moved way, one needs to think for oneself.

${ }^{28}$ The following three points show that Olympiodorus is adopting this Aristotelian view of demonstration. (i) He says that demonstrations proceed from definitions, definition here being understood as revealing a thing's essence. Thus, he says that 'all demonstration proceeds by definition' ( $\pi \tilde{\alpha} \sigma \alpha$ à $\pi$ 'ó $\epsilon \iota \xi \iota s ~ \delta \iota ' o ́ \rho \iota \sigma \mu o \tilde{v}$ $\pi \rho o ́ \epsilon \iota \sigma v$, In Phaed. 3.3.7). (ii) He says that 'demonstrations and types of knowledge are of the universal' (In Gorg. 6.2). He tells us that demonstrations are understood from causes, which I take to be a way of saying that they are explanatory of their conclusion: 'demonstrations are grasped from the causes and

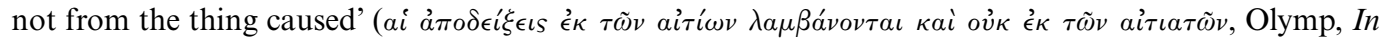
Gorg. 22, 1, 17-18). (iii) He implies that what is demonstrated is thereby known (or understood):

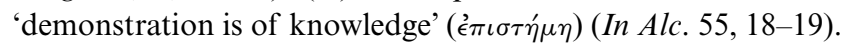


accepting these demonstrations on authority, rather than bringing them forth from yourself $?^{29}$ The answer, I think, is twofold. Having demonstrative understanding (in the sense described above) involves having two distinct, though related, abilities. First, one must be able to perform a certain kind of inference: deducing the conclusion from the premises of the demonstration. Second, one must be able to grasp a certain explanatory connection: seeing how the premises not only imply but also explain the conclusion. Each of these tasks involves more than simply accepting the truth of certain claims. First, inferring a conclusion from premises is not the same as simply believing that those premises imply that conclusion. If faced with a complicated argument, you might take it on trust that the premises imply the conclusion, without being able to see the connection between them, and hence make the inference for yourself. Second, believing that one fact explains another is not the same as grasping the explanatory connection between them. You might take it on trust that this explains that even if you are not able to see for yourself what the explanatory connection is. ${ }^{30}$

This, I suggest, explains Olympiodorus's claim that we have not fully learned something if we simply believe it on authority as if we were lifeless vessels. Of course, even when you believe on authority, you are not really entirely passive. When you

\footnotetext{
${ }^{29}$ This question is posed rather vividly by one of Olympiodorus's contemporaries, the Neoplatonist philosopher Simplicius. Simplicius is discussing the most reliable possible testimony: divine testimony. He argues that such testimony can only give you conviction, not understanding. If you hear from God that the soul is immortal, you have excellent authority for believing this, but this does not give you understanding of why the soul is immortal. For that, you would need to have a demonstration based on an explanation (ảmò $\tau \tilde{\eta} s$ aíías $\dot{\eta} a ̉ \pi o ́ \delta \epsilon \iota \xi \iota s$, Commentary on Epictetus' Handbook: 110). Simplicius goes on to consider a possible objection. Someone might say 'that he also learns the explanations from God and

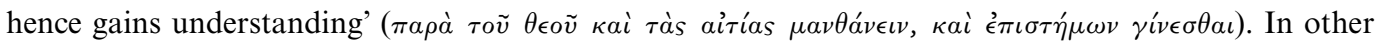
words, God might not just tell us that the soul is immortal, but explain why the soul is immortal. Why wouldn't that allow us to acquire understanding through divine testimony? Simplicius's answer to this is very brief. He says that if we acquire understanding from God, 'this is a different form of goodness, not

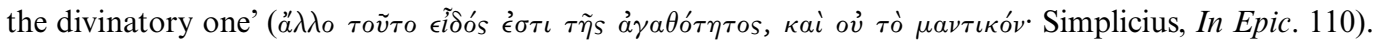
His thought, I suggest, is the following. There is a sense in which it is true that you learn the explanations from God: the sense in which this is true is that the capacity you have for grasping explanations itself comes from God. But conceding the truth of this claim is not conceding that it is possible to acquire understanding from divine testimony. Hearing the explanation from God would not be sufficient for understanding on the basis of that explanation. That is why, although there is a sense in which your understanding comes from God, you cannot acquire understanding by divination.

${ }^{30}$ For instance, I could come to believe, on expert authority, that stars are luminous and that the explanation of this is that a star has nuclear fusion reactions in its core. But to accept these claims is not to understand why the stars are luminous. I would only have understanding if I myself had a grasp of the relation between nuclear fusion and the production of light. Moreover, if I simply accept the explanatory claim on authority, I am not myself inferring that the stars are luminous from the fact that explains their luminosity (the fact about nuclear fusion). Rather, I am inferring that the stars are luminous and that this is explained by nuclear fusion from the fact that an authority figure told me this (a fact that clearly does not explain why the stars are luminous).
} 
believe something on authority, you actively judge that what you are being told is correct. ${ }^{31}$ The claim is that acquiring understanding involves a kind of active thinking that goes beyond what is required for making such a judgement and hence for believing on the basis of authority. In making an inference or grasping an explanatory connection, one must think for oneself in a way that goes beyond simply accepting the claims made by others.

If this is right, then Olympiodorus's claim does not depend on the specific, Aristotelian account of understanding that he adopts. Even if we do not agree with the view that understanding involves demonstration, we must surely allow that having understanding requires grasping explanatory relations, and possibly also having the ability to make certain kinds of inference. If so, then simply accepting claims on authority will never be enough for understanding. ${ }^{32}$ Of course, to say this is not yet to spell out exactly what is involved in having understanding.

I think we can shed some light on this - that is, on the nature of understandingby considering the second of the questions I raised above: why is such understanding valuable ${ }^{33}$ Why is it better to have the kind of understanding that involves grasping explanatory relations for oneself, rather than simply making do with the true beliefs that one might acquire on the basis of reliable authority?

Olympiodorus explains the value of understanding by invoking a remark from

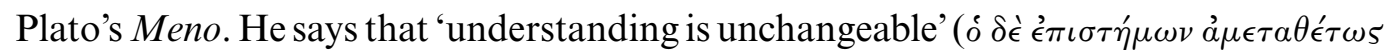
$\epsilon^{\prime \prime} \chi \epsilon \iota$, In Gorg. 9.1, 28-9), whereas opinions are likely to escape and run away from you. ${ }^{34}$ Interestingly (in the light of our earlier discussion of Cicero), Olympiodorus

${ }^{31}$ This point is made rather nicely by Simplicius. 'Even if we form a judgment this way or that way about it after we have heard someone else, providing we do form a judgment, rather than speaking like trained birds (which say 'I drink spiced wine' without knowing what they are saying), this opinion or belief is our own movement; it may sometimes be provoked from the outside or elicited by someone teaching us, but

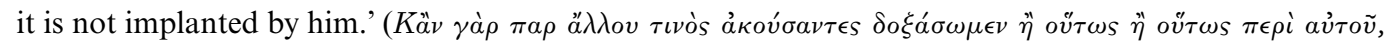

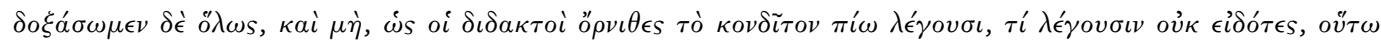

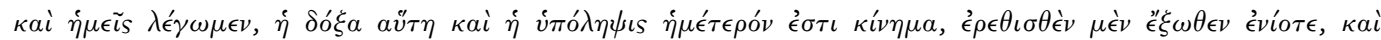

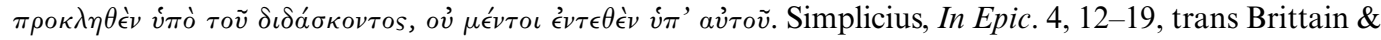
Brennan 2002a).

${ }^{32}$ For modern defences of the view that understanding must come from within see Hills (2015) and Burnyeat (1980). For a defence of the view that grasping inferential connections cannot simply be a matter of grasping propositional content, see Gardiner (2012).

${ }^{33} \mathrm{It}$ is not obvious that Olympiodorus would say that it is always better to understand for oneself instead of believing on authority. There are some passages in which he suggests that being moved by the gods is better than being self-moved. (Olymp., In Alc. 63, 10-25; 123, 3-4; 231, 14, In Phaed. 2.9.) This suggests that beliefs that result from divine inspiration might be even more valuable than beliefs grounded in one's own understanding.

${ }^{34}$ For instance, someone who understands justice has a kind of understanding that is ingrained, and such

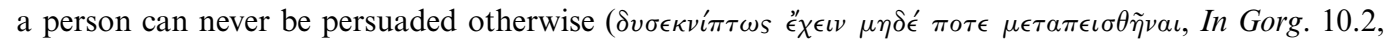
27-28). Olympiodorus is here invoking Socrates's distinction between understanding and true opinion at 
draws a connection between the stability of understanding and Socrates's boast, in the Gorgias, that he always says the same things. After quoting Socrates's claim that he always says the same things, Olympiodorus comments 'that's how secure demonstrations

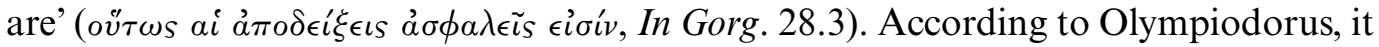
is Socrates's demonstrative understanding that enables him always to say the same thing: since he understands why what he says is true, he can never be persuaded to change his mind. This is the sense in which his beliefs do not 'run away' from him, as they would if they were not grounded in understanding.

There is, of course, an obvious objection to this view that understanding is valuable because of its stability. One does not need understanding in order to keep repeating the same true claim. For this, all that is needed is to combine true beliefs with stubbornness. The stubborn believer would simply reassert her beliefs in the face of any attempts to persuade her to the contrary. ${ }^{35}$ By considering how Olympiodorus might answer this objection, we can, I think, shed further light on what is involved in having understanding.

The key to answering this objection is to think a little more about what might be meant here by 'always saying the same thing'. I want to suggest that the person of understanding always 'says the same thing' in a deeper sense than does the person of mere belief. To have understanding is to have a certain kind of intellectual ability. If you grasp the way in which a conclusion is explained by certain premises, this enables you not merely to provide a true explanation of that conclusion, but also to exercise a more general explanatory ability, an ability to explain other similar conclusions on the basis of similar premises, to explain what is wrong with theories that deny the conclusion, and so on. ${ }^{36}$ To have such understanding is to grasp the implications of the thing you understand, and hence to be able to recognise whether or not something is consistent with the thing you understand. The sense in which the person of understanding always 'says the same thing' is thus not merely that she always repeats the same claim - rather, she is able to make use of that claim in a way that the person with mere belief is not. For instance, she is able to explain what is wrong with alternative views. Moreover, because she understands the basis for this claim, she can never be led, inadvertently, to agree to things that are inconsistent with it. By contrast, someone who merely believes on the basis of fervent conviction, without any understanding, can

\footnotetext{
Meno 97d-98a: true opinions tend to escape from us unless we tie them down with an explanatory account, thus turning them into understanding.

${ }^{35}$ For this criticism of the Meno account of the value of knowledge, see Hyman (2015: 199-200).

${ }^{36}$ For a recent defence of the view that this is what is involved in having understanding, see Hills (2015). I have also benefited from reading an unpublished paper in which Hills discusses the possible role of a teacher in the acquisition of understanding. Burnyeat (1980) claimed that having understanding involves a certain special kind of seeing for oneself. But this in itself is not very explanatory, and it does not make it very easy to see what the role of a teacher might be.
} 
easily be misled into agreeing to claims that are in fact inconsistent with the thing she so fervently believes (and in that sense, failing to 'say the same thing').

As we have seen, both Cicero and Olympiodorus hold that the Socratic method promotes a kind of independence: an independence that makes one invulnerable to being misled by argument. Cicero explicitly identifies this kind of independence with freedom; this freedom is a result of one's ability to come up with counter-arguments. For Olympiodorus, the relevant kind of independence results from the possession of understanding. Olympiodorus does not explicitly say that understanding makes you free, but he does emphasise that it makes you powerful. ${ }^{37}$ Indeed, it gives you powers that go beyond those conferred by Cicero's freedom. The possession of understanding enables you to see the value in good arguments, as well as to see what is wrong with bad arguments. Hence, the person of understanding not only has true beliefs, but also has an ability to extend her range of true beliefs on the basis of argument.

In these respects, Olympiodorus's account is more attractive than Cicero's. But is it also truer to Socrates? In some ways, it certainly is. Olympiodorus follows Socrates in recognising our responsibility for what we think and say. ${ }^{38}$ Moreover, like Socrates, Olympiodorus recognises that there is something valuable in (a certain kind of) 'always saying the same thing'. However, I shall claim that there is also an important way in which Olympidorus's view of the value of thinking for oneself departs from Socrates's. For Olympiodorus, thinking for oneself is valuable just because understanding is valuable and having understanding depends upon thinking for oneself. I shall argue that this cannot be the whole story about Socrates's view of the value of thinking for oneself.

A sign that it cannot be the whole story is that Plato's Socrates denies that he himself has the relevant kind of understanding. ${ }^{39}$ If the value of Socratic methods of

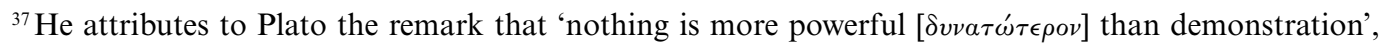
and he explains this by saying that demonstration is 'of understanding' (' $\epsilon \iota \sigma \tau \eta \dot{\eta} \mu \eta)$ and understanding cannot be taken away by a tyrant (In Alc. 55, 18-19, cf also In Alc. 36, 14-16) This claim that understanding cannot be taken away by a tyrant recalls the Stoic view that only the sage is truly free. The Stoic sage is also said to be invulnerable to the tyrant and to be someone who cannot be persuaded by argument into abandoning the truth. Given these parallels, I think it is reasonable to take Olympiodorus to be making a similar point. If this is right, then there is a sense in which Olympiodorus, like Cicero, thinks that we gain a kind of freedom when we exercise our ability to think for ourselves rather than accepting beliefs on authority.

${ }^{38}$ As Olympiodorus says, 'we assign blame to the respondent for replying badly, if falsehood follows from

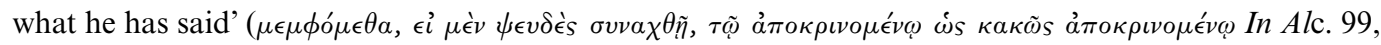
20-22).

${ }^{39}$ In Plato's dialogues, Socrates often tells his interlocutor that he himself does not have knowledge about the things they are inquiring about. See, for example, Gorgias 506a3-4, 509a4-6, Laches 200e5, and Meno 71a (where he denies that he knows what virtue is or whether it can be taught). I agree with Vlastos (1985) that we cannot take these expressions of ignorance to be ironic. For discussion of how to understand Socrates's more general remarks about his own ignorance in the Apology, see Fine (2008).
} 
inquiry comes entirely from the fact that such methods promise to result in understanding, this is a valuable outcome that Socrates himself fails to achieve. When Socrates boasts that he 'always says the same', he cannot be meaning to imply that achieving this kind of consistency is a consequence of having understanding, for he is claiming that he 'always says the same' in spite of not having such understanding. This suggests that, for Socrates, the value of inquiry cannot come entirely from its potential to result in understanding.

This point does not trouble Olympiodorus because he, like many Neoplatonists, often describes Socrates himself as a teacher ${ }^{40}$ and is inclined to explain away Socrates's disavowals of understanding. ${ }^{41}$ Sometimes he says that Socrates is merely denying that he has a kind of divine, super-human, understanding (In Gorg. 34.3). ${ }^{42}$ Elsewhere, he presents Socrates's disavowal of understanding as a kind of teaching method: it promotes learning by establishing fellow-feeling with the interlocutor. ${ }^{43}$ Olympiodorus, then, feels no need to explain how Socratic inquiry can be valuable even when it does not result in understanding.

In this respect, Cicero seems closer to Socrates. For Cicero's account offers an explanation of how Socratic methods of questioning can be valuable even when they do not result in understanding. In the final section of my paper, I shall return to some of the questions with which I started out. I shall argue that if we are to answer these questions, we need to explain how thinking for oneself is valuable even when it does not lead to understanding.

\footnotetext{
${ }^{40} \mathrm{He}$ describes Socrates as both a teacher and a midwife: 'he did not want to be a teacher only, but also a

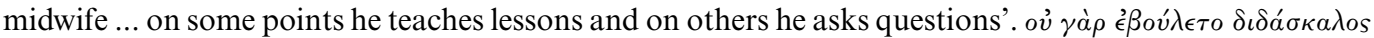

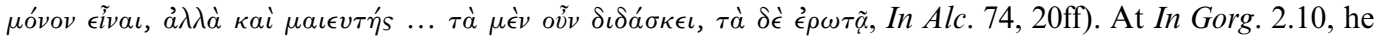
describes Socrates as 'the leader of philosophical teaching'. At In Gorg. 41.3, Socrates is assumed to be the teacher of Alcibiades. Olympiodorus raises the puzzle of how, if Socrates taught Alcibiades, Alcibiades failed to become good. In reply, he does not deny that Socrates taught Alcibiades, but asks rather: 'what can the teacher do if his students do not obey him?'

${ }^{41}$ For the claim that Socrates has knowledge, see Olympiodorus, In Alc. 88,6 (and the description of Socrates as a teacher at 88, 9-10) and In Gorg. 34.3. Olympiodorus discusses the use of irony in this connection at In Alc. 88, $5 \mathrm{ff}$.

${ }^{42} \mathrm{Of}$ course, there is some basis for this claim in Socrates's own remarks at Apology 20de.

${ }^{43}$ In Alc. 175, 7 suggests that it is part of Socrates's strategy as a teacher/midwife to act as if he is ignorant he 'takes counsel with his beloved in ignorance, even though he is a knowledgeable person with the capacity to understand [what he claims not to know]. But it's because he is a lover that he acts ignorant in company with his beloved.' (Griffin trans. See also 192,8.)
} 


\section{CONCLUSION}

I started this essay with Michael Gove's remarks about the importance of thinking for oneself rather than deferring to experts. I pointed out that these remarks raise a problem. We can all agree that there is something valuable about thinking for oneself on matters of political importance, but it is not very clear exactly why this is valuable. Moreover, we need to understand why this is valuable in order to decide what our attitude should be to experts. In modern democracies, this question about our attitude to experts is particularly pressing. On the one hand, as democratic citizens, we are called on to make decisions that are informed by matters that fall within the domain of one or other branch of expert knowledge. On the other hand, knowledge has become specialised in such a way that no one person could possibly achieve expertise in all these domains.

Olympiodorus's account of the value of thinking for oneself cannot explain why we should think for ourselves about such matters, since we can be confident that we will not achieve the kind of understanding that, for Olympiodorus, makes such thinking valuable. This suggests that we need to explain why thinking for oneself is valuable even when it does not result in understanding. Cicero offers us an account of how this might be so. Even in the absence of understanding, you can avoid being deceived if you adopt the methods of the Academic sceptic. But I have argued that this account is unconvincing: the benefits of the sceptical method come at too great a cost.

Can we, then, explain why it might be valuable to think for ourselves about these matters, rather than simply accepting the testimony of experts? I want to end by making two suggestions about this, one derived from Cicero and the other from Olympiodorus. What Cicero helps us to see, I think, is that it is possible to engage critically with expert testimony without having expert knowledge oneself. Sometimes you can see what is wrong with an argument without being able to come up with a positive alternative yourself, and sometimes you can evaluate the credentials of an alleged expert, even though you lack expert knowledge yourself. These methods need not be used in a wholly negative way - so we need not follow Cicero in being sceptics. Evaluative thinking of this sort can give you reasons for trusting one expert rather than others.

Of course, in such a case you would still be forming beliefs on the basis of expert testimony, so you would not get the special benefits that (I have claimed) come from understanding. However, I think we can draw on Olympiodorus's account to suggest a way of moving beyond mere trust in testimony, even in the absence of full understanding. This is because Olympiodorus's view of understanding leaves room for the idea that there could be degrees of understanding. As we have seen, Olympiodorus holds that someone who has achieved full understanding has a particular kind of 
cognitive ability. She not only knows that such and such is true, but she also understands why it is true. This gives her the ability to explain what is wrong with counter-arguments, to explain other similar cases, and so on. This is an ability that could come in degrees.

If there can be degrees of understanding, this opens up the possibility that we can achieve some of the benefits of understanding without having full understanding. If we can achieve a partial understanding of economic policy, climate change, and so on, that will give us an ability to resist some misleading arguments and to draw some conclusions of our own when presented with new evidence. This is an ability that we would not acquire if we simply identified the experts and formed beliefs on their authority.

Of course, partial understanding can also be dangerous. If you use mere partial understanding to arrive at your own conclusions, then it is quite possible that you will go astray. But here again, we can learn from Cicero. The intellectual practices Cicero recommends are designed, in part, to guard against mistakenly taking oneself to have understanding when one does not. Such practices can have some value even for those of us who are not sceptics. We can minimise the dangers of using partial understanding, by making sure that we do not mistakenly take ourselves to have full understanding. If we are aware that our understanding is only partial, then we shall be in a better position to assess when to rely on it.

Presumably, being aware that one's understanding is only partial should lead one to remain open to taking advice from experts. More generally, if thinking for oneself is important because of its potential to yield partial understanding, this provides no justification for ignoring the experts. Usually, the best way to arrive at such partial understanding is, precisely, to pay attention to what the experts say and to try to grasp the explanations they offer. If the argument I have given is right, then gaining understanding involves more than simply accepting these explanations. One must make these explanations 'one's own' by thinking through their implications so as to be able to apply them in a variety of contexts. In doing this, however, one is still guided by the example set by experts.

I have argued, then, that there is indeed a special value in thinking for oneself rather than simply accepting views on authority. A certain kind of thinking for oneself is valuable because it is necessary for understanding. However, this fact should not lead us to conclude that we have 'had enough' of experts. Thinking for ourselves in this way is quite compatible with being guided by experts.

Acknowledgements: In writing this paper, I have learnt from a number of experts. For comments on earlier versions, I am grateful to Tobias Reinhardt, Terry Irwin, Gail Fine, M. M. McCabe, Raphael Woolf, and to audiences at the Oxford ancient philosophy workshop, a GANPH conference at Munich, and at the British Academy lecture. 


\section{REFERENCES}

Belam, M. (2018), 'Twelve Awkward Moments from David Davis's Brexit Committee Appearance', The Guardian, 24 January.

https://www.theguardian.com/politics/2018/jan/24/david-davis-brexit-select-committee-appearancetwelve-awkward-moments

Brittain, C. (2006), Cicero: On Academic Scepticism (Indianapolis, IN, Hackett).

Brittain, C. (2015), 'Cicero's Skeptical Methods. The Example of De Finibus', in J. Annas \& G. Betegh (eds) Cicero's De Finibus, Philosophical Approaches (Cambridge, Cambridge University Press), $12-40$.

Burnyeat, M. (1980), 'Socrates and the Jury: Paradoxes in Plato's Distinction Between Knowledge and True Belief', Aristotelian Society Supplementary Volume, 54: 173-91. https://doi.org/10.1093/aristoteliansupp/54.1.173

Chatham House (2017), 'Michael Gove on the Trouble with Experts', Interview, 3 March. https://www.chathamhouse.org/expert/comment/michael-gove-trouble-experts

Cicero (1923 edn), De senectute; De Amicitia; De Divinatione with trans by W. E. Falconer (Cambridge MA, Harvard University Press).

Cicero (1931 edn), De Finibus Bonorum et Malorum with trans by H. Rackham (Cambridge MA, Harvard University Press).

Cicero (1945 edn), Tusculan Disputations with trans by J. E. King (Cambridge MA, Harvard University Press).

Cicero (1951 edn), De Natura Deorum; Academica with trans by H. Rackham (Cambridge MA, Harvard University Press).

Cicero (1956 edn), De Officiis with trans by W. Miller (Cambridge MA, Harvard University Press).

Denyer, N. (2001), Plato Alcibiades (Cambridge, Cambridge University Press). https://doi.org/10.1017/CBO9781139167079

Döring, K. (2016), Erster Alkibiades (Göttingen, Vandenhoeck and Ruprecht).

Fine, G. (2008), 'Does Socrates Claim to Know That He Knows Nothing?', Oxford Studies in Ancient Philosophy, XXXV (Winter): 49-88.

Gardiner, G. (2012), 'Understanding, Integration and Epistemic Value', Acta Analytica, 27(2): 163-81. https://doi.org/10.1007/s12136-012-0152-6

Gorman, R. (2005), The Socratic Method in the Dialogues of Cicero (Stuttgart, Franz Steiner).

Hills, A. (2015), 'Understanding Why', Nous, 49(2): 661-88.

Hutchinson, D. S. (1997), 'Alcibiades', (translation) in J. Cooper (ed.) Plato Complete Works (Indianapolis, IN, Hackett), 557-95.

Hyman, J. (2015), Action, Knowledge and Will (Oxford, Oxford University Press). https://doi.org/10.1093/acprof:oso/9780198735779.001.0001

Ince, M. (2017), 'Portes Meets Gove', Society Now, 28: 22-3.

Jackson, R., Lycos, K. \& Tarrant, H. (1998), Olympiodorus. Commentary on Plato's Gorgias. Translated with Full Notes (Leiden, Brill).

Jowett, B. (1892), 'Alcibiades I', in The Dialogues of Plato v.2. (London, Oxford University Press), 457-510. 
Kant, I. (1784), 'An Answer to the Question: What is Enlightenment?', in J. Schmidt (ed.) What is Enlightenment? Eighteenth-century Answers and Twentieth-Century Questions (Berkeley, CA, University of California Press, 1996), 58-64.

Marboeuf, C. \& Pradeau, J.-F. (1999), Platon Alcibiade (Paris, Flammarion).

Millgram, E. (2015), The Great Endarkment (New York, Oxford University Press).

Olympiodorus (1902 edn), Olympiodori prolegomena et in categorias commentarium, ed. A. Busse Commentaria in Aristotelem Graeca 12.1. (Berlin, Reimer).

Olympiodorus (1956 edn), Commentary on the First Alcibiades of Plato, critical text and indices by L. G. Westerink (Amsterdam, North-Holland).

Olympiodorus (1970 edn), Olympiodori in Platonis Gorgiam Commentaria, ed. L. G. Westerink (Leipzig, B. G. Teubner Verlagsgesellschaft).

Olympiodorus (2009 edn), The Greek Commentaries on Plato's Phaedo: I Olympidorus, edited with translation by L. G. Westerink (Westbury, Prometheus Trust).

Olympiodorus (2015 edn), Life of Plato and on Plato First Alcibiades 1-9, trans with comments by M. Griffin (London, Bloomsbury).

Olympiodorus (2016 edn), On Plato First Alcibiades 10-28, trans with comments by M. Griffin (London, Bloomsbury).

Philoponus (1899 edn), De Aeternitate Mundi Contra Proclum, ed. H. Rabe (Leipzig, Teubner).

Plato (1922 edn), Platonis Opera, v1, 2 and 3, ed. J. Burnet (Oxford, Oxford University Press).

Simplicius (1996 edn), Commentaire sur le Manuel d'Épictète: introduction et edition critique du texte grec, by I. Hadot, Philosophia Antiqua 66 (Leiden, Brill).

Simplicius (2002a edn), On Epictetus' Handbook 1-26, trans with comments by C. Brittain \& T. Brennan (Ithaca, NY, Cornell University Press).

Simplicius (2002b edn), On Epictetus' Handbook 27-53, trans with comments by C. Brittain \& T. Brennan (Ithaca, NY, Cornell University Press).

Thorsrud, H. (2010), 'Arcesilaus and Carneades', in R. Bett (ed.) The Cambridge Companion to Ancient Scepticism (Cambridge, Cambridge University Press), 58-80.

https://doi.org/10.1017/CCOL9780521874762.004

Thorsrud, H. (2012), 'Radical and Mitigated Skepticism in Cicero's Academica', in W. Nicgorski (ed.), Cicero's Practical Philosophy (Notre Dame, IN, University of Notre Dame Press), 133-51.

Vlastos, G. (1985), 'Socrates's Disavowal of Knowledge', Philosophical Quarterly, 35(138): 1-31. https://doi.org/10.2307/2219545

Woolf, R. (2015), Cicero. The Philosophy of a Roman Sceptic (London, Routledge). https://doi.org/10.4324/9781315724850

Wynne, J. (2018), 'Cicero', in D. Machuca \& B. Reed (eds) Skepticism from Antiquity to the Present (London, Bloomsbury), 93-101.

Note on the author: Ursula Coope is Professor of Ancient Philosophy at Oxford University and a Fellow of Keble College, Oxford. She has published articles on Aristotle, Ps-Simplicius and Aquinas. Her book Time for Aristotle (OUP, 2005) discusses Aristotle's account of time. She is currently working on another book, Freedom and Responsibility in Neoplatonist Thought.

ursula.coope@philosophy.ox.ac.uk

To cite the article: Ursula Coope (2019), 'Free to think? Epistemic authority and thinking for oneself', Journal of the British Academy, 7: 1-23.

DOI https://doi.org/10.5871/jba/007.001 
This article is licensed under a

Creative Commons Attribution-NonCommercial-NoDerivatives 4.0 International License.

Journal of the British Academy (ISSN 2052-7217) is published by

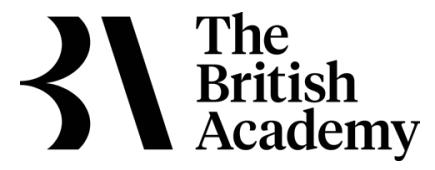

10-11 Carlton House Terrace, London, SW1Y 5AH

www.thebritishacademy.ac.uk 
